$\begin{array}{r}\text { Business and Economics Research Journal } \\ \text { Volume } 8 \text { Number } 42017 \\ \text { pp. } 797-813 \\ \text { ISSN: } 1309-2448 \\ \text { www.berjournal.com } \\ \hline\end{array}$

\title{
Öz-liderlik Becerilerinde Psikolojik Sermayenin Rolü: Kamu Çalışanları Üzerine Görgül Bir Araştırma ${ }^{1}$
}

\author{
Meral Kızrak
}

\author{
Papatya S. Bıçakçı ${ }^{\mathrm{b}}$
}

\author{
H. Nejat Basım ${ }^{\mathrm{c}}$
}

\begin{abstract}
Öz: Bu çalışmada çalışanların öz-liderlik becerilerine etki eden psikolojik sermaye faktörlerinin ortaya çıkarılması hedeflenmiştir. Bu amaçla psikolojik sermayenin dört alt boyutunun (umut, iyimserlik, psikolojik dayanıklıık, öz-yeterlilik), özliderlik değişkeninin sekiz alt boyutu (kendine hedef belirleyerek başarılı performans hayal etme, doğal ödüller üzerinde düşünceyi odaklama, kendini gözlemleme, kendini ödüllendirme, kendini cezalandırma, kendine hatırlaticılar belirleme, kendi kendine konuşma, düşünce ve fikirlerini değerlendirme) üzerindeki etkileri araştırılmıştır. Anket tekniğinin kullanıldığı araştırmada kolayda örnekleme yöntemiyle, Ankara ilinde çalışan 227 kamu çalışanından veri toplanmış, veri analizi ve model testi için yapısal eşitlik modellemesi yaklaşımından faydalanılmıştır. Çalışma sonucu elde edilen bulgulara göre, farklı öz-liderlik davranışları farklı psikolojik sermaye faktörlerinden, özellikle umut ve iyimserlik alt boyutundan, etkilenmektedir. Diğer taraftan umut hariç diğer üç psikolojik sermaye faktörüyle etkileşim içinde olan tek değişkenin kendine hatirlatıclar belirleme davranışı olduğu; kendini ödüllendirme ve kendini cezalandırma davranışları üzerinde ise psikolojik sermaye yapısının herhangi bir alt boyutunun etkili olmadığı saptanmıştır. Bu çerçevede çalışanların psikolojik sermayesinin öz-liderlik becerileri üzerinde kısmi etki yarattı̆ı̆ belirlenmiştir.
\end{abstract}

Anahtar Sözcükler: Psikolojik Sermaye, Öz-liderlik, Pozitif Örgütsel Davranış, Yapısal Eşitlik Modeli

JEL Sınıflandırması: M12, M53, M54, J24

\section{The Role of Psychological Capital in Self-leadership: An Empirical Research on State Officials}

\begin{abstract}
This study aims to explore the psychological capital factors which may affect self-leadership skills. To this aim, the effects of four sub-constructs of psychological capital (hope, optimism, resilience, self-efficacy) on eight sub-constructs of self-leadership (self-goal setting \& visualizing successful performance, focusing thoughts on natural rewards, selfobservation, self-reward, self-punishment, self-cuing, self-talk, evaluating beliefs and assumptions) have been investigated. The research data were obtained from 227 state officials in Ankara through questionnaires and convenience sampling. For the data analysis and model test, the structural equation modeling was utilized. The research findings indicate that different selfleadership behaviors are affected by different psychological factors, particularly hope and optimism. On the other hand, the findings reveal that self-cueing is influenced by each psychological factor except for hope. The results also show that none of the psychological sub-constructs has an effect on self-reward or self-punishment. Within this context, employees' psychological capital has been found to have a partial impact on their self-leadership skills.
\end{abstract}

Keywords: Psychological Capital, Self-leadership, Positive Organizational Behavior, Structural Equation Model

JEL Classification: M12, M53, M54, J24

\footnotetext{
aLecturer, Başkent University, School of Foreign Languages, Ankara, Turkiye, mkizrak@baskent.edu.tr

${ }^{b}$ Res. Asst., Başkent University, Faculty of Economics and Administrative Sciences, Department of Management, Ankara, Turkiye, papatyas@baskent.edu.tr

cProf., PhD., Başkent University, Faculty of Economics and Administrative Sciences, Department of Management, Ankara, Turkiye, nbasim@baskent.edu.tr
} 


\section{Giriş}

Çalışanların öz-liderlik becerilerine sahip olması örgütlerin yenilikçilik ve esneklik gereksinimlerini karşılayabilecek en önemli unsurlardan biri olarak değerlendirilmektedir (Pearce ve Manz, 2005: 133). Bu açıdan bakıldığında, dış zorlamalara gerek duymadan, kendi kendini motive edebilen, başkalarına bağımlı olmadan bireysel ve örgütsel hedefler belirleyebilen, bu amaçlar doğrultusunda hareket ederken gösterdiği performansı kendi için anlamlı kılabilen, davranış, düşünce ve fikirleriyle yapıcı olmaya çalışan öz-liderlik düzeyi yüksek bireyler örgütler için önemli stratejik kaynaklar olarak değerlendirilmektedir.

Çalışanların öz-liderlik becerilerinin yanı sıra, psikolojik sermaye düzeylerinin de olumlu örgütsel çıktlar üzerinde önemli etkiler yarattğı bildirilmektedir (Avey, Reichard, Luthans ve Mhatre, 2011). Luthans, Luthans ve Luthans'a (2004: 45-46) göre, örgütlerin finansal kaynakları (neye sahip olduğu), insan kaynakları ve sosyal sermayesi (çalışanlarının neyi bildiği ve kimi tanıdığı) kadar, pozitif psikolojik sermayesi (çalışanlarının kim olduğu) de örgütlerin sürdürülebilir rekabet avantajı elde etmeleri için önemli örgütsel kaynaklardan biridir. Bir anlamda psikolojik sermaye, örgütlerin sahip olduğu iş gücüne olumlu yönde yatırım yapabilecekleri nitelikler bütünü olarak görülmektedir (Luthans, Norman, Avolio ve Avey, 2008: 224).

Görüldüğü gibi hem öz-liderlik davranışları hem de psikolojik sermaye, örgüt çalışanlarında arzu edilen beceriler ya da durumlar kapsamında ele alınmaktadır. Birbirlerinden farklı kavramsal açıklamalara sahip olan bu yetkinliklerden öz-liderlik, bireylerin davranış odaklı, yapıcı düşünce ve doğal ödül stratejileri uygulayarak, kendi performans çıktılarını bilişsel ve motivasyonel olarak şekillendirmesini ifade eder (Houghton ve Neck, 2002: 673). Pozitif psikoloji akımına (Seligman ve Csikszentmihalyi, 2000) dayanan psikolojik sermaye ise umut, iyimserlik, dayanıkılık, öz-yeterlilik bileşenlerinin oluşturduğu psikolojik nitelikler bütünü olarak kavramsallaştrılmıştır (Luthans vd., 2004: 46). Bu noktada, birey ve örgüt performansına olumlu katkılar sunabilecek bu iki kavramın birbiri ile ilişkili olabileceği ileri sürülebilir. Psikolojik olarak dayanıklı, hayata umut dolu ve iyimser bir bakış açısıyla yaklaşan, kendi kapasite ve öz yetkinlik algılarına güvenen bireylerin kendine liderlik edebilme yetilerinin yüksek düzeyde olabileceği iddia edilebilir.

Psikolojik sermaye yapısının örgütsel bağlılık ve iş tatmini (Akçay, 2011; Çetin, 2011; Çetin ve Basım, 2011); performans (Luthans, Youssef ve Rawski, 2011); bireysel yaratıcılık (Wu, 2015); ruh sağlığı (Dina, Lester ve Harms, 2015); örgütsel vatandaşlık (Sharma ve Sharma, 2015) gibi olumlu çıktılara aynı yönde etki ettiği de bildirilmektedir. Bu kapsamda, psikolojik sermayenin çalışanların öz-liderlik davranışlarını da etkileyebileceği ve bireylerde farklı düzeyde öz-liderlik davranışlarının gözlemlenmesine neden olabileceği düşünülmektedir. Diğer taraftan Kotze'nin (2017) çalışması, öz-liderlik becerilerinin psikolojik sermayenin belirleyicisi olduğu yönünde bulgular sunmaktadır ancak ilgili literatürde psikolojik sermayenin öz-liderlik becerilerini etkileyebileceğine yönelik çıkarımlar dikkat çekmektedir. Örneğin bireylerin öz-liderlik yöneliminin bireysel, durumsal ve kültürel farklılıklar gibi değişkenlerle etkileşim içinde olabileceği kuramsal olarak tartışılmaktadır (D'Intino, Goldsby, Houghton ve Neck, 2007). Bu farklılıklara bağlı olarak, bazı çalışanların öz-liderlikte daha iyi olabileceği, diğerlerinin ise aynı düzeyde öz-liderlik davranışları sergileyemeyeceği ileri sürülmektedir (Manz, 1986: 596).

Dolayısıyla bu çalışmada "Psikolojik sermaye faktörleri, çalışanların öz-liderlik becerilerinin bir belirleyicisi olabilir mi?" sorusu yanıtlanmaya çalışılmış ve alt boyutlar temelinde ilişkisel bir model kurgulanmıştır Bu kapsamda, öncelikle öz-liderlik ve psikolojik sermaye yapıları açıklanmış ve aralarındaki ilişkiler kavramsal ve kuramsal olarak tartışımıştır. Ulusal ya da uluslararası yazın incelemesinde bu değişkenlerin birbirleriyle ilişkisini ele alan çalışmaların sınırlı olması nedeniyle elde edilecek bulguların ilgili literatüre katkı sağlayacağı, insan kaynağı geliştirme ve personel güçlendirme uygulamalarında, performans değerlendirme sürecinde ve çaţ̧̧ma yönetimi yaklaşımlarında uygulamacılara önemli çıkarımlar sunabileceği düşünülmektedir. Ayrıca Luthans'ın da (2002: 698) eleştirtiği gibi, örgütsel davranış alanında yapılan çalışmalara bakıldığında yoğunluklu olarak olumsuzlukları önleme üzerine araştırmalar gözlemlenmektedir. Diğer bir deyişle örgütsel aktörlerin güçlü yönleri ve performanslarını arttıran psikolojik kapasiteleri yerine stres, tükenmişlik, değişime direnç gibi işlevsizlik ve yetersizlik yaratan konular ilgi görmektedir. Bu görüşten 
hareketle, mevcut araştırma örgüt çalışmalarında görülmeye başlanan pozitif psikoloji yönelimine görgül olarak katkıda bulunmayı da amaçlamaktadır.

\section{Kavramsal Çerçeve}

\section{1. Öz-liderlik}

Bireyin kendi kendini motive etmesi ve davranışlarına yön vermesi olarak açıklanan (Manz ve Sims, 1991: 23; Neck, 1996: 203) öz-liderlik , bilişsel, motivasyonel ve öz-etkileme becerilerini kapsayan öğrenilebilir taktikler bütünü olarak tanımlanmaktadır (Manz ve Sims, 1991: 30; Pearce ve Manz, 2005: 133). Öz-liderlik olgusundaki temel varsayım, bireylerin kendi eylemlerini gözlemleyebileceği, bu eylemlerle ilgili değerlendirmeler yapabileceği ve bunun sonucunda da arzu edilmeyen davranışlarını değiştirebileceğidir (Neck, 1996: 203).

Öz-liderlik kavramı kökenlerini öz-düzenleme, öz-denetim ve öz-yönetim gibi kuramlardan almaktadır (Manz, 1986: 595; Pearce ve Manz, 2005: 133). Bununla birlikte, bireyin kendi belirlediği üst düzey performans hedeflerini gerçekleştirmesini, doğal yollarla kendi kendini motive etmesini ve öz-disiplinle kendini yönetmesini de kapsayan bir modeldir (Manz, 1986: 595; Pearce ve Manz, 2005: 133). Bir diğer deyişle, öz-liderlik, öz-yönetim modelinde yer alan bireyin dış standartlar ile davranışları arasındaki uyumu arttırma çabalarının ötesine geçerek, bu standartların birey için ne anlama geldiğine de vurgu yapar (Neck, 1996: 203). Belli bir davranışın gerçekleşmesi için ne yapılması gerektiğini ve neden yapılması gerektiğini vurguladığı gibi, nasıl yapılması gerektiğini de işaret eder (Pearce ve Manz, 2005: 133). Sonuç olarak, "özliderlik, birey davranışının merkezine, yapılacak işin bireye hitap eden niteliksel önemini, anlamlılı̆ını ve bireyi doğal olarak motive edecek çekici yönlerini yerleştirir" (Manz, 1986: 590).

Araştırmacılar tarafindan öz-liderlik modelinin davranış odaklı stratejiler, doğal ödül ve yapıcı düşünme stratejileri biçiminde üç kategoriden oluştuğu ileri sürülmektedir (Houghton ve Neck, 2002: 673; Pearce ve Manz, 2005: 133; Tabak, Sığrı ve Türköz, 2013). Mevcut çalışmada da bu kavramsal sınıflandırma benimsenmiştir.

\subsubsection{Davranış Odaklı Stratejiler}

Davranış odaklı stratejiler genel olarak bireyin etkili davranışlar sergilemek için benimsediği stratejilerdir (Manz ve Sims, 1991: 23). Bu stratejiler olumlu ve arzu edilen davranışların pekiştirilmesini sağlarken, olumsuz ve başarısız çıktlara neden olan davranışların terk edilmesini amaçlar (Houghton ve Neck, 2002: 673).

Davranış odaklı stratejilerden biri hedef belirleme davranışıdır. Bireyin başarılması çok da kolay olmayan hedefler belirlemesi ve gerçekleştirmesi, tatmin ve başarma duygusunun gelişmesine neden olmaktadır (Locke ve Latham, 2006: 266). Bu durum hem bireyin davranışlarına olumlu anlamda yön vermekte hem de genel iyi olma haline katkılar sağlamaktadır (Locke ve Latham, 2006: 266). Hedef belirleme davranışı, çalışanların performans çıktısı için motive olmalarını sağlayarak, gösterdikleri çabaların belli bir amaç doğrultusunda gerçekleştirilmesine neden olmaktadır (Latham ve Locke, 1979: 79). Dolayısıyla hedef belirleme davranışı, kişisel çıkarlara hizmet eden bireysel hedeflerin başarılması anlamına geldiği gibi, performans hedeflerine ulaşılması gibi örgütsel amaçları da içinde barındırmaktadır (Marques-Quinteiro ve Curral, 2012: 562).

Bir diğer davranış odaklı strateji de bireyin kendini ödüllendirmesidir. Bu davranış, öz-değerlendirme davranışı sonucu (Manz ve Sims, 1980: 364) bireyin kendi belirlediği standartları yerine getirdiğinde kendini, örneğin bir kahve arası vererek ödüllendirmesi (Davis ve Luthans, 1980: 288) ya da zor bir işi başardıktan sonra zihninde kendini takdir etmesi gibi soyut ödüllerle kendini motive etmesidir (Houghton ve Neck, 2002: 673).

Bireyin kendini cezalandırması ya da eleştirmesi de davranış odaklı öz-liderlik stratejisi kapsamında değerlendirilmektedir. Bu davranış biçiminde birey kendini değerlendirerek, arzu edilmeyen, yanlış bir davranışını değiştirmek için kendi iradesiyle caydırıcı önlemler alır (Manz ve Sims, 1980: 364; 1991: 23). Bir 
anlamda birey kendi belirlediği davranış standartlarını yerine getirmediği zaman, örneğin evrak işiyle yeterince ilgilenmediğini düşündüğünde, her gün yarım saat daha fazla ofiste çalışmaya karar vererek kendine cezalar uygular (Davis ve Luthans, 1980: 288). Aslında kendini cezalandırma taktiği bir nevi kendine geri dönüş sağlama biçiminde gerçekleşmektedir: başarısızlıkların veya arzulanmayan davranışların olumlu bir çerçevede irdelenmesini ve yeniden yapılandırılmasını içermektedir (D'Intino vd., 2007: 106). Bu noktada kendini eleştirme davranışının etkili ve tutarlı bir şekilde uygulandığı zaman yüksek performansa sebep olduğu ancak aşırıya kaçıldığında birey için olumsuz etkiler yaratabileceği de bildirilmektedir (Manz ve Sims, 1991: 24).

Kendini gözlemleme davranışı da davranış odaklı öz-liderlik modelinin alt bileşenlerinden sayılmaktadır. Kendini gözlemleme, bireyin kendi eylemlerinin farkına varıp denetlemesini (Manz ve Sims, 1991: 24), nasıl, ne zaman ve neden belirli davranışları sergilediğine dair bilinçlenmesini (Houghton ve Neck, 2002: 673; D'Intino vd., 2007: 106), bu değerlendirmeler ışığında davranışının olası sonuçları üzerinde içgörü sahibi olmasını ve nihayetinde de hangi davranışını pekiştirmesi gerektiğine dair kendisine birtakım müdahale stratejileri tasarlamasını sağlayan davranış biçimidir (Davis ve Luthans, 1980: 287; Manz ve Sims, 1980: 364).

Kendi kendine hatırlatıcılar belirleme stratejisi de davranış odaklı öz-liderlik yaklaşımı olarak ele alınmaktadır. Bu yaklaşımda birey, hedeflediği davranışı yerine getirmeden önce değiştirmek istediği davranışına neden olan uyarıcıları öz değerlendirme sonucunda kontrol altına alır ve böylece planladığı davranış değişikliklerini gerçekleşir (Davis ve Luthans, 1980: 287). Örneğin, iş yerinde kişisel konularda sohbet etme davranışını azaltmak isteyen bir çalışan, ofis kapısını kapatarak, davranış uyarıcısını (koridordan geçenleri görme) ortadan kaldırıp, arzu edilmeyen davranışını azaltmaya çalışır (Manz ve Sims, 1980: 364). Aynı şekilde notlar, listeler, ekran koruyucuları, poster gibi görseller yardımıyla da birey çevresinde birtakım uyarıcı materyaller bulundurup, amaçladığı hedef davranışı ve sonucunda elde edebileceği olumlu çıktıları kendisine hatırlatabilir (D'Intino vd., 2007: 106; Marques-Quinteiro ve Curral, 2012: 562).

\subsubsection{Doğal Ödül Stratejileri}

Öz-liderlik yapısının doğal ödüller üzerinde düşünceyi odaklama olarak adlandırılan alt boyutuna göre birey doğal ödül stratejileriyle kendi davranışlarına yön vererek olumlu davranışlarını pekiştirebilir. Bu stratejilerle birey, herhangi bir eylemin doğasında var olan keyifli ve mutluluk verici unsurlarına odaklanarak (D'Intino vd., 2007: 116) ya da bu eyleme kendisi birtakım kişisel tatlar katarak performans düzeyini arttrabilir (Houghton ve Neck, 2002: 673; Marques-Quinteiro ve Curral, 2012: 562). Örneğin, yapılacak işte seyahat imkanı varsa ve birey de seyahat etmekten hoşlanıyorsa, dikkatini işinin bu yönüne vererek kendi kendini motive edebilir. Aynı şekilde sevdiği müzikleri çalarak ya da beğendiği resimleri odasına asarak çalışt̆ğı ortamı eğlenceli hale getirip performas düzeyini arttrabilir (Houghton ve Neck, 2002: 673). Bu perspektiften bakıldığında doğal ödül stratejileriyle, hedeflenen davranışla ilgili deneyim ve algıların olumlu yönde değiştirilmesi mümkündür (Prussia vd., 1998: 524). Böylece, bireyin öz-güveni artacağı için performansının da artacağı beklenir (D'Intino vd., 2007: 107).

\subsubsection{Yapıcı Düşünce Stratejileri}

Temellerini Bandura'nın (1977; 1986) sosyal biliş kuramından alan bu stratejiler, düşünce süreçlerinin yönetimi olarak tanımlanmaktadır (Manz, 1986: 594). Bu yaklaşımdaki temel varsayım, bireyin kendi düşünme eylemini yönetebilecek güce sahip olmasıdır (Neck ve Manz, 1992: 682). Buna paralel olarak bireyin bilişsel stratejilere başvurarak kendi düşüncelerini şekillendirebileceği (Neck ve Manz, 1992: 681) ve olumsuz, rasyonel olmayan düşünce ve varsayımları değiştirip, olumlu ve yapıcı düşünce kalıpları geliştirebileceği varsayılır (Prussia, Anderson ve Manz, 1998: 524; Houghton ve Neck, 2002: 674; Marques-Quinteiro ve Curral, 2012: 562). Sonuç olarak, etkili düşünmeyi teşvik eden bu beceriler (Manz ve Sims, 1991: 24), sadece dış pekiştireçlerle değil aynı zamanda bireyin bilişsel süreçlerini kendi iradesiyle düzenlemesi sonucu gerçekleşir (Neck ve Manz, 1992: 686).

Mükemmelliyetçilik, diğerlerine bağımlılık, toplumsal onay alma isteği, aşırı genellemelerde bulunma gibi işlevsel olmayan düşünce süreçleri (Houghton ve Jinkerson, 2007: 46) yapıcı düşünce stratejileri 
uygulayarak değişikliğe uğratılabilir. Yapıcı düşünce kalıpları geliştirebilmek için de bireylerin uygulayabileceği üç davranış taktiği önerilmektedir: başarılı performans hayal etme, kendi kendine konuşma ve düşünce ve fikirleri değerlendirme. Başarılı performans hayal etme, bireyin görevini yerine getirmeden önce başarılı performans gösterdiğini zihninde sembolik olarak betimlemesini işaret eder (Neck ve Manz, 1992: 684). Örneğin toplum önünde sunum yapacak bir yönetici, performansı sonrası başarılı olduğunu zihninde canlandırırsa, sunum performansında da başarılı sonuçlar elde edecektir (Neck, 1996: 206). Bu şekilde başarının zihinde resmedilmesi, yapılacak işten daha çok zevk alınmasına, öz-güvenin artmasına ve dolayısıyla performans düzeyinin artmasına neden olabilir (Neck, 1996: 205).

Yapıcı düşünce stratejilerinden kendi kendine konuşma ise, bireyin kendisiyle diyalog kurmasıdır (Neck ve Manz, 1992: 689). Birey bu stratejiyle olumsuz ve yıkıcı iç diyaloglar yerine pozitif ve yapıcı iç konuşmalar yaparak düşünme biçimini olumlulama şansını elde eder (Houghton ve Neck, 2002: 674; D'Intino vd., 2007: 107). İçsel konuşmalar bilinç düzeyine çıkarılır, üzerinde tekrar düşünülür ve yine kendi kendine seslendirilir, böylece birey kendisiyle yaptığı konuşmaları içselleştirerek olumsuz algılarını değiştirip (Neck, 1996: 205) performans düzeyini arttrabilir (Neck ve Manz, 1992: 684).

Düşünce ve fikirleri değerlendirme boyutu ise bireyin işlevsel olmayan düşünce ve varsayımlarıyla yüzleşip onları daha rasyonel düşüncelerle değiştirmesini işaret eder (Neck, 1996: 205; D'Intino vd., 2007: 107). Bu davranış yönelimiyle birey, bilişsel sistemini öz-düzenleme yoluyla tekrar yapılandırıp zorlukların üstesinden daha kolay gelebilir (Neck, 1996: 212). Bu stratejilerin geliştirilmesindeki temel neden bireyin genel olarak firsatçı düşünme ve engelli düşünme biçiminde iki tarz düşünce yaklaşımını benimseme eğilimidir (Neck ve Manz, 1992: 690). Fırsatçı düşünme, bireyin firsatlara, kendisine değer katacak zorluklara ve bu zorluklarla yapıcı bir biçimde başa çıkma yöntemlerine yoğunlaştı̆̆ düşünce kalıplarını ifade ederken, engelli düşünme bireyin karşılaştğı zor durumların olumsuz taraflarına yönelen düşünce kalıplarını ifade eder (Neck, 1996: 206). Düşünce ve fikirleri değerlendirme stratejisiyle birey, performansına yönelik işlevsel olmayan düşüncelerini değiştirip, zihinsel enerjisini performansının olumlu taraflarına yönlendirir ve nihayetinde de motivasyon düzeyini arttrarak olumlu düşünce kalıpları geliştirir (Manz, 1986: 594).

\subsection{Psikolojik Sermaye}

Çalışmanın diğer bir değişkeni olan psikolojik sermaye kavramı, kuramsal temellerini pozitif psikoloji yaklaşımından almaktadır. Bu yaklaşım, bireyin patalojik, zayıf ve hasarlı yönlerinden ziyade güçlü, psikolojik olarak sağlıklı, gelişime ve zenginleşmeye açık yönlerine vurgu yaparak, psikoloji biliminin artık "sadece hasarı onarmak değil, [bireyin sahip olduğu] en iyiyi yeşertmek" amacı gütmesi gerektiğini savunur (Seligman ve Csikszentmihalyi, 2000: 7).

Fred Luthans (2002) öncülüğündeki pozitif psikoloji düşüncesi evrilerek pozitif örgütsel davranış olarak adlandırılmış ve bu alanda önemli bir paradigma değişikliğine neden olmuştur (Luthans, Youssef ve Rawski, 2011: 335). Sonrasında da pozitif örgütsel davranış yaklaşımı, psikolojik sermaye olarak tanımlanmıştır (Luthans ve Youssef, 2004). Psikolojik sermaye, temelinde pozitiflik barındıran ve statik olmayan bireysel bir durumu ifade etmektedir (Luthans vd., 2007: 544). Bu psikolojik durum, pozitif duygulanım, öz disiplin, öz saygı gibi her koşul ve durumda süreklilik gösteren kişiye özgü karakteristik bir özellik değil duruma göre farklılaşan bir niteliktir (Luthans, 2002: 698; Luthans, Avey, Avolio ve Peterson, 2010: 44; Çetin ve Basım, 2012: 123). Bu bağlamda psikolojik sermaye yapısı, eğitim ile şekillendirilebilir, değişime ve gelişime açık, pozitif psikolojik yetkinlikler ve nitelikler bütünü olarak kavramsallaştırılmaktadır (Luthans vd., 2004: 46; Luthans, 2002: 699; Youssef ve Luthans, 2007: 776).

Pozitif sermaye yapısınının umut, iyimserlik, psikolojik dayanıklıık, öz-yeterlilik boyutlarından oluştuğu hem görgül hem de kuramsal yazında oldukça geniş yer bulmaktadır (Luthans vd., 2008; Avey, Reichard, Luthans ve Mhatre, 2011). Bu alt boyutların kavramsal ve psikometrik olarak birbirinden farklı olmasına rağmen temelde aynı psikolojik kaynağı paylaşmaları, psikolojik sermaye yapısının üst seviyede çekirdek bir yapı olarak değerlendirilmesine neden olmaktadır. (Luthans vd., 2008: 224; Luthans vd., 2011: 335). Dolayısıyla psikolojik sermaye, birbiriyle entegre olan ve performans çıktları üzerinde sinerjik etki yaratan niteliklerin oluşturduğu tek bir kuramsal yapıdır. (Luthans vd., 2010: 48). 


\subsubsection{Umut}

Pozitif bir durum olan umut kavramı iki boyutlu bilişsel bir yapı olarak tanımlanmaktadır. Bu boyutlardan temsil, bireyin belli bir amaca yönelik davranışını gerçekleştirmek için sahip olduğu kararılılı̆ı, motivasyonu ve irade gücünü; metodlar ise bireyin bu hedeflerine ulaşmak için bilişsel yol ve yöntemler üretebilme becerisini işaret etmektedir (Snyder vd., 1991). Temsil ve metodlar, amaç-yönelimli düşünme sürecinin farklı iki unsuru olmasına rağmen birbiriyle etkileşim içindedir (Snyder vd., 1996) ve birindeki bir değişim diğerinde de değişiklik yapılmasını gerektirir (Snyder vd., 1991).

Dolayısıyla umut hem amacı gerçekleştirme isteğini hem de amacın gerçekleştirilmesi için gereken alternatif yolları kapsamaktadır (Çetin ve Basım, 2012: 123). Umutlu insanlar, amaçladıkları hedeflere yöneldiklerinde karşılarına çıkabilecek engellerin üstesinden gelmek için birçok alternatif plan geliştirebilir (Peterson ve Byron, 2008: 786). Bu bireyler amaçlarına ulaşmaya çalışırken fayda sağlamayacak metodları eleyip alternatif çözüm arayışları geliştirme azmini göstererek arzuladıkları performans çıktılarını elde edebilirler (Youssef ve Luthans, 2007: 778). Bu bakımdan umut, örgüt çalışanlarının psikolojik sermayesine önemli katkılar sağlayan ve performanslarına olumlu yönde etki eden bir unsur olarak görülmektedir (Çetin ve Basım, 2012: 124).

\subsection{2. İyimserlik}

İyimserlik, kendine güven olgusunun daha genelleştirilmiş bir biçimi olarak değerlendirilmektedir (Carver, Scheiner ve Segerstrom, 2010: 880). Bireyin neler başarabileceğini ya da başaramayacağını gerçekçi bir biçimde değerlendirmesini (Luthans vd., 2007: 547), tersliklerle karşılaştğında başarı azminden ve hedeflerinden vazgeçmemesini (Carver vd., 2010: 880), başarısızlık durumunda ise suçluluk hislerinden uzaklaşıp (Youssef ve Luthans, 2007: 779), cesaretini toplayarak kararlılıkla meselelerin üzerine gitmesini (D'Intino vd., 2007: 108) ve geleceğe ilişkin iyi ve olumlu beklentilerin gelişmesini sağlayan pozitif bir beceridir (Reichard vd., 2011: 132). İyimser bireyler, yaşama dair zorlukların gelip geçici olduğunu düşünürken, olumlu gelişmelerin kalıcı ve yerleşik olduğuna inanırlar (Luthans vd., 2004: 47). Bu bireyler duygusal olarak daha güçlü, sorunlarla başa çıkma stratejilerini daha etkin kullanan, olaylara iyi tarafindan bakan, problem çözümünde daha ılımlı (Carver vd., 2010: 887) ve mevcut kaynakları değerlendirerek başarıya ulaşacaklarına inanan bireylerdir (Reichard vd., 2011: 132).

\subsubsection{Psikolojik Dayanıklııı}

Psikolojik dayanıklılık kavramı stresli ve büyük değişimler içeren koşullarda psikolojik olarak dayanıkııığını koruyabilme (Coutu, 2002: 8); bireysel gelişim sürecini kesintiye uğratabilecek olumsuzluklara pozitif bir şekilde uyum sağlayabilme ve daha önceki dayanıklılık durumunu tekrar kazanabilme yetisini işaret etmektedir (Luthar, Cicchetti ve Becker, 2000: 543). Diğer bir deyişle, psikolojik dayanıklılık, yaşanan sorun ve problemlerden sonra "yenilenmek için gereken pozitif psikolojik kapasitedir" (Luthans, 2002: 702).

Psikolojik olarak dayanıklı bireyler terslikler yaşandığında gerçeklerle yüzleşebilir ve yaşamın sorunlara rağmen anlamlı olduğuna dair güçlü bir inanç geliştirirler (Coutu, 2002: 8). Ellerindeki kaynakları, yaratıcılıklarını en iyi şekilde kullanarak çözümler yaratıp kendilerini toplarlar (Coutu, 2002: 8). Bu şekilde bireyler gelecekte kendilerini bekleyen sorunlarla daha iyi başa çıkabilmek için beceriler repertuarı oluştururlar (Mills, Fleck ve Kozikowski, 2013: 154) ve benzer problemler karşısında psikolojik olarak daha da dayanıklı olurlar (Luthans vd., 2007: 547).

Belirsizlik ve değişim gibi bireyin esneklik ve uyum sağlama yetisini gerektiren durumlarda psikolojik dayanıklılığa daha fazla ihtiyaç duyulmaktadır (Youssef ve Luthans, 2007: 780). O nedenle örgütsel ortamda çalışan bireylerin psikolojik dayanıklılığııın örgütün çalkantılı dönemlerinde krizlerden başarıyla çıkmasına etki edebileceği düşünülmektedir (Mills vd., 2013).

\subsection{4. Öz-yeterlilik}

Öz-yeterlilik, insanların belirli bir performans düzeyine çıkabilmek için kendi yeteneklerine yönelik sahip oldukları inançlar olarak tanımlanır (Bandura, 1994: 71). Bireyin kendi kapasitesine yönelik bu inanç ve 
kararlılığı, hislerine, düşünce ve davranışlarına yansımaktadır (Gist, 1987: 472). Bandura'ya (1977: 194) göre bireylerin öz-yeterlilik düzeyleri, yani başarıya ulaşabileceklerine yönelik inançları farklılıklar göstermektedir. Bu farklılıkları belirleyen değişkenler, bireyin hedeflediği görevin zorluk düzeyi, bu zorluk karşısında ne derece azimli olduğu ve yaşanan deneyimin genel ya da duruma özel bir nitelik taşımasıdır (Bandura, 1977: 194).

Bandura (1989), bireylerin öz-yeterlilik algılarının, bilişsel, duygusal ve davranışsal birtakım süreçleri harekete geçirdiğini ileri sürmektedir. Buna göre, bireyin öz-yeterlilik algısı ne kadar yüksekse, birey kendisi için başarması daha zor amaçlar belirleyip, bu amaçlarını gerçekleştirmek için davranışlarına yön verir. Özyeterlilik algıları bireyin duygusal yetkinliklerine yönelik kendisine olan inancını da etkileyerek stresli unsurlarla baş etmesini ve kaygı durumunu kontrol altnna almasını sağlar (Bandura, 1989: 1175). Bandura (1994), ayrıca öz-yeterlilik algısının bireyin önceki başarı deneyimlerinden ilham almasıyla, başarısızık deneyimlerinden ders çıkarmasıyla, diğerlerince başarabileceği konusunda ikna edilmesiyle veya özdeşim geliştirdiği toplumsal modelleri gözlemlemesiyle gelişebileceğini öne sürmektedir.

\section{3. Öz-liderlik ve Psikolojik Sermaye İlişkisi}

D'Intino vd. (2007), birtakım bireysel farklılıkların öz-liderlik olgusunu şekillendirebileceği gibi özliderlik taktiklerinin de bu farklııkları ortaya çıkarabileceğine dikkat çekmiş, öz-liderliğin iyimserlik, mutluluk, hayata olumlu yaklaşma gibi pozitif psikolojik niteliklerle ve kontrol odağı, öz-gözlemcilik, özerklik ihtiyacı gibi kişilik özelliklerinin, hatta bireyin yaşı, cinsiyeti veya ait olduğu kültürün özellikleri ile karşlıklı etkileşim içinde olduğunu kuramsal olarak tartışıştır. (D'Intino vd., 2007). Dolayısıyla öz-liderlik davranışlarının birtakım kişisel değişkenlerle etkileşim içinde olduğu anlaşılmaktadır. Bu noktada psikolojik sermaye faktörlerinin, bireyin öz-liderlik becerilerini öğrenme ve uygulama yönelimleriyle ilişkili olabileceği ileri sürülebilir. Özliderlik ve psikolojik sermaye arasında muhtemel bir ilişkiye yönelik ip uçlarını bu iki alanda yapılmış görgül çalışmalardan elde edilen bulgularda da görmek mümkündür. Örneğin, 51 bağımsız örneklem üzerinde çalışılan bir meta analiz sonucuna göre (Avey vd., 2011: 127), psikolojik sermaye ile olumlu tutum ve davranışlar (iş doyumu, örgütsel bağlılık, psikolojik iyi olma hali, örgütsel vatandaşıı) ve bir çok performans göstergesi (öz, amir değerlendirmeleri ve hedef) arasında önemli düzeyde pozitif ilişki saptanmıştır. Aynı çalışmada psikolojik sermaye ile olumsuz tutum ve davranışlar (sinizm, iş bırakma niyeti, iş stresi, kaygı, işyerinde sapkın davranış) arasında da anlamlı ölçüde ters yönlü ilişki saptanmıştır.

Diğer çalışmalarda da psikolojik sermaye yapısının olumlu örgütsel çıktılarla aynı yönde, olumsuz çıktılarla ise ters yönde ilişkili olduğu ifade edilmektedir. Örneğin, psikolojik sermaye düzeyinin, performans geri dönüşü ve bireylerin gelecekteki psikolojik sermaye düzeyleri (Luthans vd., 2011), iş tatmini (Culbertson, Fullagar ve Mills, 2010), yaratıclık (Sweetman, Luthans, Avey ve Luthans, 2011), örgütsel vatandaşlık davranışları, örgütsel bağlılık ve performans (Norman, Avey, Nimnicht ve Pigeon, 2010); kariyer gelişimi (Cenciotti, Alessandri ve Borgogni, 2017) ile pozitif yönde; iş yerinde sapkın davranışlar (Norman vd., 2010), örgütsel sinizm, ayrılma niyeti (Avey, Wernsing ve Luthans, 2008) ve tükenmişlik (Çetin, Hazır ve Basım, 2013) ile ters yönlü ilişkili olduğu ve ayrıca çalışanların işyerinde yaratıcı ve yenilikçi davranışlar (Jafri, 2012) sergilemelerine sebep olduğu saptanmıştır. Psikolojik sermayenin alt bileşenleriyle ilgili yapılan çalışmalarda ise iyimserliğin yaratıcı davranışa (Rego, Sousa, Marques ve Cunha, 2012), öz-yeterliliğin yaratıcı performansa neden olduğu (Tierney ve Farmer, 2002) ve performansı doğrudan ve pozitif yönde etkilediği (Prussia, Anderson ve Manz, 1998: 534), psikolojik olarak dayanıklı bireylerin iyimser, enerjik, meraklı ve yeni deneyimlere açık olduğu (Block ve Kremen, 1996) bildirilmektedir.

Öz-liderlik stratejileri üzerine yapılan çalışmalara bakıldığında ise bu değişkenin yaraticılık (DiLiello ve Houghton, 2006), yenilikçi davranışlar (Carmeli, Meitar ve Weisberg, 2006; Park, Moon ve Hyun, 2014), özyeterlilik ve iş performansı (Konradt, Andreßen ve Ellwart, 2009), iş tatmini ve örgütsel bağlılık (Şeşen, Tabak ve Arli, 2017) değişkenlerini pozitif yönde etkilediği, işe gelmeme davranışını ise ters yönde etkilediği bildirilmiştir (Frayne ve Latham, 1987). Alt bileşenlere yönelik çalışmalarda ise davranış odaklı stratejilerin, pro-aktif iş rolü performansını yordadığı (Marques-Quinteiro ve Curral, 2012), yapıcı düşünce stratejilerinin ise zihinsel performans, olumlu duygulanım ve iş tatmini seviyelerinde artışa neden olduğu (Neck ve Manz, 1996) ve iş tatmini üzerine aynı yönde etki yarattğı anlaşıımıştır (Houghton ve Jinkerson, 2007). 
Tüm bu bulgular incelendiğinde, öz-liderlik ve psikolojik sermaye düzeyi arttğında arzulanan örgütsel tutum ve davranış düzeyinde de artı̧ gözlemlenmekte, olumsuz davranış ve performans çıktları ise azalmaktadır. Ayrıca bu iki değişkenle ilişki içinde olan yaratıcı ve yenilikçi örgütsel davranış, artan performans ve iş tatmini gibi ardıl değişkenlerin varlığı, öz-liderlik ve psikolojik sermaye arasında anlamlı bir ilişki olabileceği, bireylerin farklı psikolojik sermaye düzeyinin öz-liderlik davranışları üzerinde önemli etkiler yaratabileceği izlenimi vermektedir. Bireyin psikolojik sermaye düzeyinin öz-liderlik davranışlarına etki edebileceği iddiasının temelini, Bandura'nın (1989) öz-yeterlilik algısı yüksek bireylerin belirledikleri hedefler doğrultusunda motive olup bu amaçla kendilerine yön verebilecekleri yönündeki düşüncesi oluşturmaktadır. Bu çıkarımdan hareketle psikolojik sermaye bileşenlerinden öz-yeterlilik algısının öz-liderlik yöneliminde rolü olabileceği; benzer şekilde umut düzeyi yüksek bireylerin amaçlarını gerçekleşirmek için kararlı olma ve alternatif yöntemler geliştirebilme becerilerinin daha yüksek olabileceği beklenebilir. Ayrıca, iyimser, psikolojik olarak dayanıklı ve öz-yeterlilik algısı yüksek bireylerin belirledikleri amaçlar için davranışlarına daha kolay yön verebileceği, kendi eylem, algı ve düşünce yapısını daha objektif bir biçimde değerlendirip işlevsel olmayanları öz-liderlik stratejileriyle değiştirebileceği de düşünülebilir. Buraya kadar ifade edilen kuramsal gerekçeler ışı̆ıında psikolojik sermaye alt boyutlarının öz-liderlik alt boyutları üzerindeki etkilerini incelemeye yönelik kurgulanan araştrrma modeli Şekil 1'de gösterilmiştir.

Şekil 1. Araştırmanın Modeli

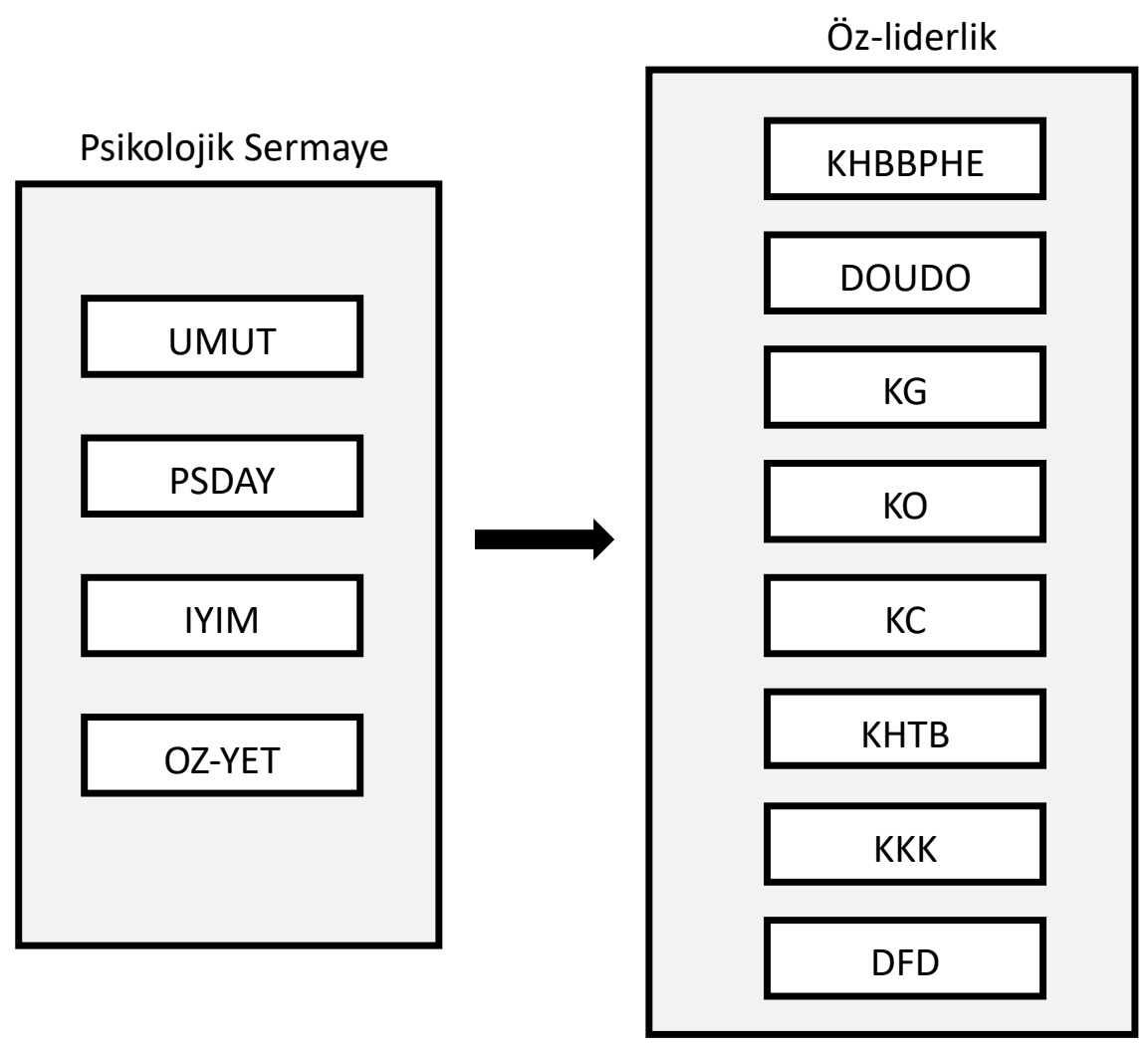

UMUT: Umut; PSDAY: Psikolojik dayanıklılık; IYIM: İyimserlik; OZYET: Öz-yeterlilik; KHBBPHE: Kendine hedef belirleyerek başarılı performans hayal etme; DOUDO: Doğal ödüller üzerinde düşünceyi odaklama; KG: Kendini gözlemleme; KO: Kendini ödüllendirme; KC: Kendini cezalandırma; KHTB: Kendine hatırlatıcılar belirleme; KKK: Kendi kendine konuşma; DFD: Düşünce ve fikirlerini değerlendirme.

Bu kapsamda, kurgulanan model doğrultusunda oluşturulan hipotezler aşağıda sunulmuştur.

$H_{i, j}:$ Psikolojik sermaye değişkeninin i. alt boyutu öz-liderlik değişseninin j. alt boyutunu etkiler.

$\mathrm{i}=1,2,3,4 ; 1:$ UMUT; 2:PSDAY; 3:IYIM; 4:OZ-YET

$\mathrm{j}=1,2,3,4,5,6,7,8 ; 1: K H B B P H E ; 2: D O U D O ; 3: K G ; 4: K O ; 5: K C ; 6: K H T B ; 7: K K K ; 8: D F D$ 


\section{Yöntem}

\section{1. Örneklem}

Uygun örnekleme (convenience sampling) yönteminin benimsendiği bu çalışmada, veriler Ankara'da Bakanlıklarda ve bunların bağlı olduğu kuruluşlarda çalışan 227 kişiden yüzyüze anket tekniğiyle toplanmıştır. Örnekleme ilişkin demografik özellikler Tablo 1'de sunulmuştur.

Tablo 1. Örnekleme ilişkin Demografik Özellikler

\begin{tabular}{lcc} 
DEMOGRAFiK ÖZELLiKLER & Sayı & Yüzde \\
\hline Cinsiyet & & \\
\hline Kadın & 119 & 52,4 \\
Erkek & 108 & 47,6 \\
Toplam & 227 & 100,0 \\
\hline Medeni durum & & \\
\hline Bekâr & 59 & 26,0 \\
Evli & 158 & 69,6 \\
Boşanmış & 10 & 4,4 \\
Toplam & 227 & 100,0 \\
\hline Yaş & & \\
\hline $21-30$ & 45 & 19,8 \\
$31-40$ & 110 & 48,5 \\
$41-50$ & 55 & 24,2 \\
$51-60$ & 15 & 6,6 \\
$61-70$ & 1 & 0,4 \\
$71-80$ & 1 & 0,4 \\
Toplam & 227 & 100,0 \\
\hline Eğitim durumu & & \\
\hline Lise & 15 & 6,6 \\
Yüksekokul & 17 & 7,5 \\
Üniversite & 103 & 45,4 \\
Yüksek lisans & 63 & 27,8 \\
Doktora & 29 & 12,8 \\
Toplam & 227 & 100,0 \\
\hline & & \\
\hline & & \\
\hline
\end{tabular}

\subsection{Veri Toplama Araçları}

\subsubsection{Psikolojik Sermaye Ölçeği}

Luthans vd. (2007) tarafindan geliştirilen, Çetin ve Basım (2012) tarafindan Türkçe'ye uyarlanan Psikolojik sermaye ölçeği 4 boyut (iyimserlik, psikolojik dayanıkılık, umut ve öz-yeterlilik) ve 21 maddeden oluşmaktadır. Ölçeğin yapı geçerliliği için gerçekleştirilen doğrulayıcı faktör analizi sonuçları Tablo 2'de gösterilmiştir. Ölçeğin güvenirliğine ilişkin elde edilen Cronbach Alfa değerleri Tablo 4'de verilmiştir.

Tablo 2. Psikolojik Sermaye Ölçeğinin Doğrulayıcı Faktör Analizi Sonuçları

\begin{tabular}{ccccccc} 
& $\mathbf{X}^{\mathbf{2}}$ & $\mathbf{X}^{\mathbf{2}} / \mathbf{s d}$ & TLI & IFI & CFI & RMSEA \\
\hline $\begin{array}{c}\text { Psikolojik sermaye ölçeği } \\
\text { (21 madde) }\end{array}$ & 391,438 & 2,224 & 0,91 & 0,91 & 0,92 & 0,074
\end{tabular}

$\mathrm{X}^{2}$ : ki-kare, sd: serbestlik derecesi, TLI: Tucker Lewis indeksi, IFI: Artırmalı uyum indeksi, CFI: Karşılaştırmalı uyum indeksi, RMSEA: Yaklaşık hataların ortalama karekökü. 


\subsection{2. Öz-liderlik Ölçeği}

Revize Edilmiş Öz-liderlik Ölçeği ilk olarak Anderson ve Prussia (1997) tarafindan geliştirilmiş ve daha sonra Houghton ve Neck (2002) tarafindan doğrulayıcı analiz çalışmaları yapılmıştır. Türkçe'ye Tabak, Sığrı ve Türköz (2013) tarafindan uyarlanan ölçek 8 boyut ve 29 maddeden oluşmaktadır. Ölçeğin yapı geçerliliğinin sınanması için doğrulayıcı faktör analizi yapılmış ve analiz sonuçları Tablo 3'de gösterilmiştir. Ölçeğin güvenirliğine ilişkin elde edilen Cronbach Alfa değerleri Tablo 4'de verilmiştir.

Tablo 4. Güvenirlik Analizleri

DEĞiŞKEN

\section{Cronbach Alfa}

Psikolojik Sermaye

Umut

Psikolojik dayanıklılık

0,90

0,76

İyimserlik

0,72

0,69

Öz-yeterlilik

0,81

\section{Öz-liderlik}

0,86

Kendine hedef belirleyerek başarılı performans hayal etme

0,83

Doğal ödüller üzerinde düşünceyi odaklama

0,65

Kendini gözlemleme

0,70

Kendini ödüllendirme

0,89

Kendini cezalandırma

0,76

Kendine hatırlatıcılar belirleme

0,85

Kendi kendine konuşma

0,79

Düşünce ve fikirlerini değerlendirme

0,65

Iligili yazında genel olarak kabul gören yaklaşımlar çerçevesinde Cronbach Alfa katsayısının 0,65 ve üzerinde olması gerekliliği belirtilmektedir (Aron ve Aron, 1999). Bu doğrultuda, ölçeklerin yeterli güvenirliği sağladığı görülmektedir.

\subsection{Bulgular}

Araştırmada yer alan psikolojik sermaye ve öz-liderlik değişkenlerinin alt boyutlarına ilişkin betimleyici istatistikler Tablo 5'de sunulmuştur.

Tablo 5. Değişkenlere Ait Betimleyici İstatistikler

\begin{tabular}{lccccc} 
DEĞişKEN & TOPLAM & MiN. & MAKS. & ORT. & SS. \\
\hline Psikolojik Sermaye & & & & & \\
\hline Umut & 227 & 1 & 6 & 4,690 & 0,715 \\
Psikolojik dayanıklılık & 227 & 1 & 6 & 4,744 & 0,719 \\
İyimserlik & 227 & 1 & 6 & 4,258 & 0,797 \\
Öz-yeterlilik & 227 & 1 & 6 & 4,859 & 0,711 \\
\hline Öz-liderlik & & & & & \\
\hline Kendine hedef belirleyerek başarılı performans hayal etme & 227 & 1 & 5 & 3,600 & 0,707 \\
Doğal ödüller üzerinde düşünceyi odaklama & 227 & 1 & 5 & 3,909 & 0,692 \\
Kendini gözlemleme & 227 & 1 & 5 & 3,943 & 0,578 \\
Kendini ödüllendirme & 227 & 1 & 5 & 3,380 & 0,994 \\
Kendini cezalandırma & 227 & 1 & 5 & 3,170 & 0,756 \\
Kendine hatırlatıcılar belirleme & 227 & 1 & 5 & 3,317 & 1,158 \\
Kendi kendine konuşma & 227 & 1 & 5 & 3,348 & 0,913 \\
Düşünce ve fikirlerini değerlendirme & 227 & 1 & 5 & 3,973 & 0,499 \\
\hline
\end{tabular}


Psikolojik sermayenin öz-liderlik üzerindeki etkilerinin incelenmesi amacıyla yapısal eşitlik modeli kurulmuştur. Birinci aşama olarak, yapısal modellerin geçerliliği seçilen örneklemle doğrulanmıştr. Bu aşama ile ilgili sonuçlar bir önceki kısımda verilmiştir. İkinci aşamada, doğrulanan yapısal modeller arası ilişkileri araştırmak üzere ilişkisel model kurulmuştur. Ilişkisel modelde psikolojik sermaye alt boyutları bağımsız değişken, öz-liderlik alt boyutları ise bağımlı değişken olarak ele alınmıştır. Kurulan yapısal eşitlik modeline ilişkin elde edilen tüm etkileşimler Tablo 6 'da verilmiştir. Her iki değişkenin birlikte ele alındığı modelin uyum indekslerine bakıldığında Ki-kare 2,288; TLI 0,914; IFI 0,980; CFI 0,979 ve RMSEA değeri 0,075 olarak bulunmuştur.

Tablo 6. Regresyon Ağırlıkları (Tüm etkileşimler)

\begin{tabular}{|c|c|c|c|c|c|c|}
\hline \multicolumn{2}{|c|}{ Test edilen yol } & \multirow{2}{*}{$\begin{array}{l}\text { Tahmin } \\
0,375\end{array}$} & \multirow{2}{*}{$\begin{array}{l}\text { Std. hata } \\
0,094\end{array}$} & \multirow{2}{*}{$\begin{array}{l}\text { Kritik oran } \\
3,871\end{array}$} & \multirow{2}{*}{$\begin{array}{l}\text { P değeri } \\
* * *\end{array}$} & \multirow{2}{*}{$\begin{array}{l}\text { Sonuç } \\
\mathrm{H}_{1,1} \text { kabul }\end{array}$} \\
\hline KHBBPHE & <--- UMUT & & & & & \\
\hline DOUDO & <--- UMUT & 0,483 & 0,098 & 4,768 & $* * *$ & $\mathrm{H}_{1,2}$ kabul \\
\hline KG & <--- UMUT & 0,631 & 0,072 & 7,048 & $* * *$ & $\mathrm{H}_{1,3}$ kabul \\
\hline KO & <--- UMUT & 0,18 & 0,158 & 1,58 & 0,114 & $\mathrm{H}_{1,4}$ ret \\
\hline KC & <--- UMUT & $-0,119$ & 0,121 & $-1,04$ & 0,298 & $\mathrm{H}_{1,5}$ ret \\
\hline КНТВ & <--- UMUT & 0,151 & 0,173 & 1,407 & 0,159 & $\mathrm{H}_{1,6}$ ret \\
\hline KKK & <--- UMUT & $-0,014$ & 0,143 & $-0,128$ & 0,898 & $\mathrm{H}_{1,7}$ ret \\
\hline DFD & <--- UMUT & 0,112 & 0,07 & 1,118 & 0,263 & $\mathrm{H}_{1,8}$ ret \\
\hline \multicolumn{2}{|c|}{ KHBBPHE <--- PSDAY } & $-0,136$ & 0,083 & $-1,572$ & 0,116 & $\mathrm{H}_{2,1}$ ret \\
\hline DOUDO & <--- PSDAY & $-0,019$ & 0,087 & $-0,206$ & 0,837 & $\mathrm{H}_{2,2}$ ret \\
\hline KG & <--- PSDAY & $-0,119$ & 0,064 & $-1,488$ & 0,137 & $\mathrm{H}_{2,3}$ ret \\
\hline KO & <--- PSDAY & $-0,033$ & 0,141 & $-0,320$ & 0,749 & $\mathrm{H}_{2,4}$ ret \\
\hline KC & $<---$ PSDAY & 0,028 & 0,107 & 0,271 & 0,787 & $\mathrm{H}_{2,5}$ ret \\
\hline КНТВ & <--- PSDAY & $-0,193$ & 0,154 & $-2,014$ & $0,044^{*}$ & $\mathrm{H}_{2,6}$ kabul \\
\hline KKK & <--- PSDAY & 0,017 & 0,127 & 0,170 & 0,865 & $\mathrm{H}_{2,7}$ ret \\
\hline DFD & <--- PSDAY & 0,064 & 0,062 & 0,717 & 0,473 & $\mathrm{H}_{2,8}$ ret \\
\hline KHBBPHE & $<---\mid$ IYIM & 0,229 & 0,061 & 3,267 & $0,001 * *$ & $\mathrm{H}_{3,1}$ kabul \\
\hline DOUDO & <--- IYIM & $-0,026$ & 0,064 & $-0,357$ & 0,721 & $\mathrm{H}_{3,2}$ ret \\
\hline KG & <--- IYIM & 0,097 & 0,046 & 1,506 & 0,132 & $\mathrm{H}_{3,3}$ ret \\
\hline KO & <--- IYIM & 0,061 & 0,102 & 0,764 & 0,455 & $\mathrm{H}_{3,4}$ ret \\
\hline KC & <--- IYIM & 0,014 & 0,078 & 0,166 & 0,869 & $\mathrm{H}_{3,5}$ ret \\
\hline КНTВ & <--- IYIM & 0,203 & 0,112 & 2,619 & $0,009 * *$ & $\mathrm{H}_{3,6}$ kabul \\
\hline KKK & <--- IYIM & 0,197 & 0,092 & 2,440 & $0,015^{*}$ & $\mathrm{H}_{3,7}$ kabul \\
\hline DFD & $<---$ IYIM & $-0,015$ & 0,045 & $-0,200$ & 0,841 & $\mathrm{H}_{3,8}$ ret \\
\hline KHBBPHE & <--- OZ-YET & 0,135 & 0,093 & 1,416 & 0,157 & $\mathrm{H}_{4,1}$ ret \\
\hline DOUDO & <--- OZ-YET & 0,035 & 0,097 & 0,355 & 0,722 & $\mathrm{H}_{4,2}$ ret \\
\hline KG & $<---$ OZ-YET & 0,033 & 0,071 & 0,375 & 0,708 & $\mathrm{H}_{4,3}$ ret \\
\hline KC & <--- OZ-YET & $-0,076$ & 0,120 & $-0,676$ & 0,499 & $\mathrm{H}_{4,4}$ ret \\
\hline KO & $<---$ OZ-YET & $-0,018$ & 0,157 & $-0,162$ & 0,872 & $\mathrm{H}_{4,5}$ ret \\
\hline КНTВ & <--- OZ-YET & 0,238 & 0,172 & 2,255 & $0,024^{*}$ & $\mathrm{H}_{4,6}$ kabul \\
\hline KKK & <--- OZ-YET & 0,081 & 0,141 & 0,730 & 0,465 & $\mathrm{H}_{4,7}$ ret \\
\hline DFD & $<---$ OZ-YET & 0,363 & 0,069 & 3,669 & $* * *$ & $\mathrm{H}_{4,8}$ kabul \\
\hline
\end{tabular}

***p<0,001; ${ }^{* *} p<0,01 ;{ }^{*} p<0,05$; UMUT: Umut; PSDAY: Psikolojik dayanıklılı; IYIM: İyimserlik; OZYET: Öz-yeterlilik; KHBBPHE: Kendine hedef belirleyerek başarılı performans hayal etme; DOUDO: Doğal ödüller üzerinde düşünceyi odaklama; KG: Kendini gözlemleme; KO: Kendini ödüllendirme; KC: Kendini cezalandırma; KHTB: Kendine hatırlatıcılar belirleme; KKK: Kendi kendine konuşma; DFD: Düşünce ve fikirlerini değerlendirme.

Psikolojik sermaye alt boyutları arasındaki ilişkilere bakıldığında en güçlü ilişkiler sırasıyla, umut ile öz-yeterlilik arasında ( $r=0,78, p<0,001)$; psikolojik dayanıklılık ile öz-yeterlilik arasında ( $r=0,70, p<0,001)$; umut ile psikolojik dayanıklılık arasında $(r=0,69, p<0,001)$; psikolojik dayanıklılık ile iyimserlik arasında $(r=0,57$, $p<0,001)$; umut ile iyimserlik arasında $(r=0,54, p<0,001)$ ve iyimserlik ile öz-yeterlilik arasında $(r=0,46$, $\mathrm{p}<0,001)$ gerçekleşmiştir. 
Psikolojik sermaye alt boyutlarının öz-liderlik alt boyutları üzerindeki etkileri incelendiğine, psikolojik dayanıklılık ile kendine hatırlatıcılar belirleme arasında $(b=-0,19, p<0,05)$ ters yönlü bir etkileşim gerçekleştiği görülmüştür. Bunun dışında anlamlı bulunan tüm etkileşimler aynı yönlüdür. Aynı yönlü en güçlü etkileşimlerin sırasıyla, umut ile kendini gözlemleme arasında $(b=0,63, p<0,001)$, umut ile doğal ödüller üzerinde düşünceyi odaklama arasında $(b=0,48, p<0,001)$; umut ile kendine hedef belirleyerek başarılı performans hayal etme arasında $(b=0,38, p<0,001)$; öz-yeterlilik ile düşünce ve fikirlerini değerlendirme arasında $(b=0,36, p<0,01)$; öz-yeterlilik ile kendine hatılaticılar belirleme arasında $(b=0,24, p<0,05)$; iyimserlik ile kendine hedef belirleyerek başarılı performans hayal etme arasında $(b=0,23, p<0,01)$; iyimserlik ile kendine hatırlatıcılar belirleme arasında $(b=0,20, p<0,01)$ ve iyimserlik ile kendi kendine konuşma arasında $(b=0,20$, $p<0,05)$ gerçekleştiği görülmüştür. Kurulan yapısal eşitlik modeline ilişkin anlamlı bulunan etkiler Şekil 2 'de verilmiştir.

Şekil 2. Anlamlı Bulunan Etkiler

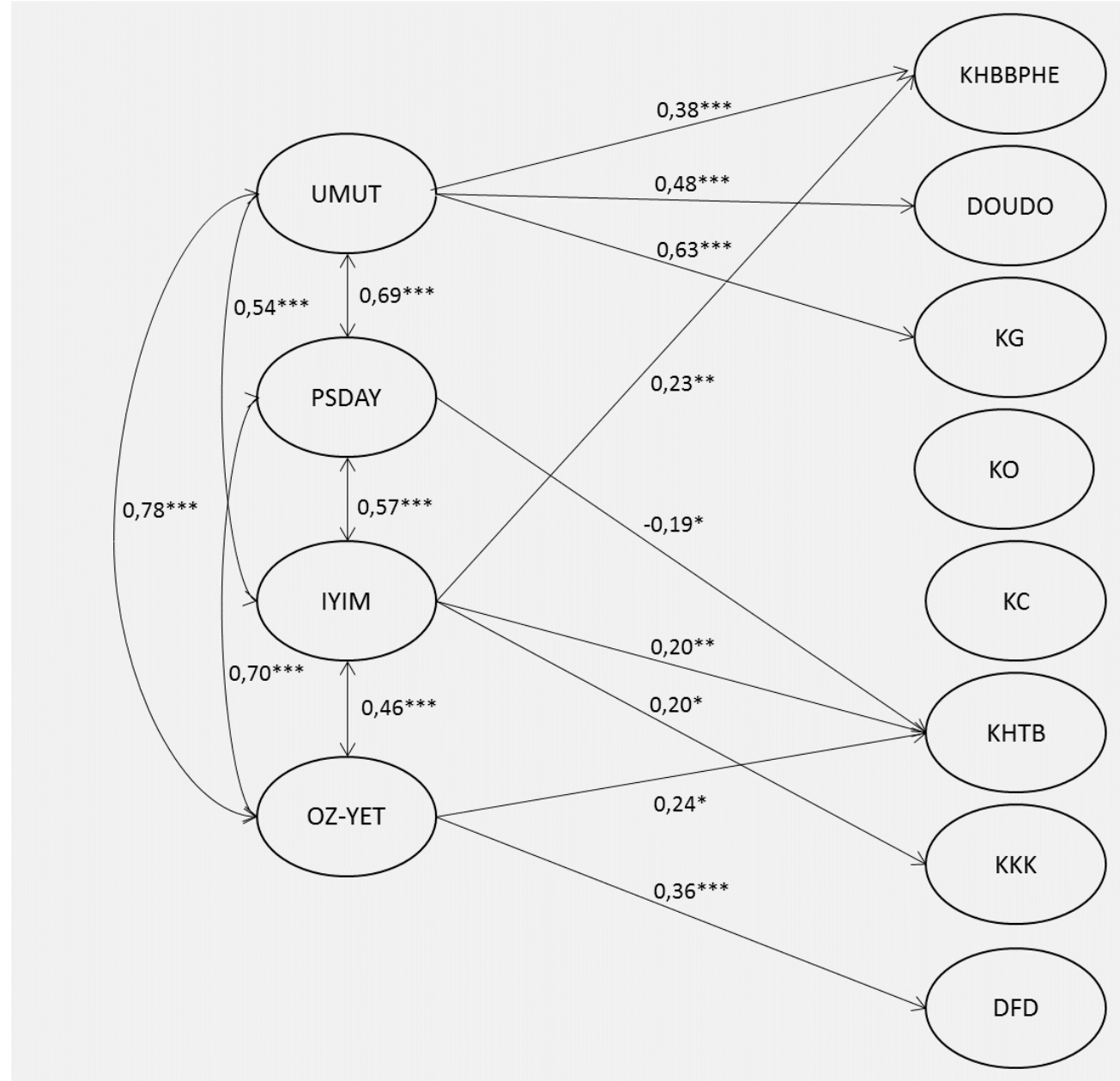

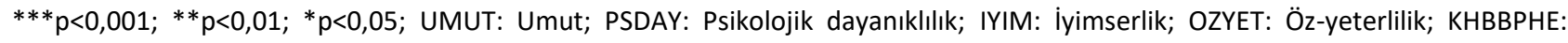
Kendine hedef belirleyerek başarılı performans hayal etme; DOUDO: Doğal ödüller üzerinde düşünceyi odaklama; KG: Kendini gözlemleme; KO: Kendini ödüllendirme; KC: Kendini cezalandırma; KHTB: Kendine hatırlatıcılar belirleme; KKK: Kendi kendine konuşma; DFD: Düşünce ve fikirlerini değerlendirme.

\section{Tartışma ve Sonuç}

Örgütlerde bazı çalışanların öz-disiplin ve öz-yönetim becerileri yüksekken, diğerlerinin dış uyarıcılar ya da standartlar olmaksızın performansını yönetme, kendi kendini motive etme konusunda zorlandığı gerçeği dikkat çekmektedir. Mevcut çalışmada, bu sorunsala ilişkin bir yaklaşım getirme hedeflenmiş ve kamu sektöründen seçilen bir örneklem üzerinde çalışanların psikolojik sermayesinin öz-liderlik davranışları üzerindeki olası etkileri araştırılmıştır. Çalışmada elde edilen bulguların, pozitif psikoloji düşüncesine, pozitif 
örgütsel davranış çalışmalarına ve insan kaynakları uygulayıcılarına önemli bir katkı sağlayacağı düşünülmektedir.

D'Intino vd. (2007), bireylerin öz-liderlik stratejilerini uygulama düzeylerinde özellikle pozitif nitelikler taşıyan bireysel farklııkların etkili olabileceğini ifade etmektedir. Mevcut çalışmanın bulguları da D'Intino vd.'nin (2007) değerlendirmesini kısmen destekler niteliktedir. Çalışanların psikolojik sermayesini oluşturan unsurlardan özellikle umut ve iyimserlik niteliklerinin, öz-liderlik becerilerinin bazıları üzerinde önemli bir etki yaratabileceği bu çalışmanın dikkat çeken bulguları arasındadır. Ayrıca umut hariç diğer üç psikolojik sermaye faktörlerinden de etkilenen tek değişkenin kendine hatırlatıılar belirleme davranışı olduğu saptanmıştr. Diğer taraftan öz-liderlik becerilerinden kendini ödüllendirme ve kendini cezalandırma davranışları üzerinde psikolojik sermaye bileşenlerinden herhangi bir faktörün anlamlı bir etkisi saptanamamıştır. Bu bulgunun gerekçesi olarak, araştırmada veri toplama yönteminin öz değerlendirmeye dayanması ve bu nedenle örneklem grubunun kendini ödüllendirme ve kendini cezalandırma davranışlarını zayıflık ya da zafiyet olarak değerlendirmiş olabileceği düşünülmektedir.

Psikolojik sermaye ve öz-liderlik yapılarını oluşturan alt boyutların birbiriyle ilişkisi daha detaylı değerlendirilecek olursa farklı çıkarımlar elde edilebilir. Psikolojik sermaye alt boyutlarından umut, bireyin hedeflediği amaca ulaşmak için sahip olduğu kararlılı̆̆ı; amaca giden yolda sorunlarla karşılaştiğında çaresizliğe kapılmadan alternatif yön ve yöntemler geliştirebilme becerisini ifade etmektedir (Synder vd., 1991; Youssef ve Luthans, 2007; Çetin ve Basım, 2012). Örgütsel bağlama yönelik bir çalışmada, umut düzeyi yüksek çalışanların daha yaratıcı performans sergilediği bildirilmektedir (Sweetman vd., 2011; Taştan, 2016). Başka bir çalışmada umut ve bilişsel psikoterapi ilişkilendirilmektedir. Bu çalışmada (Cheavens, Feldman, Woodward ve Snyder, 2006), hedef belirleme, problem çözme, kendi kendine olumlu yönde konuşma, işlevsel olmayan düşünceleri kontrol altnna alma gibi teknikler "umut dolu düşünme teknikleri" olarak ele alınmış ve bu tekniklerin bilişsel psikoterapi yöntemi olarak kullanılabileceği tartşııımıştır. Mevcut çalışmada elde edilen bulgular da bu araştırmalarla benzerlik göstermektedir. Çalışmada umut alt boyutunun, öz-liderlik becerilerinden kendini gözlemleme, doğal ödüller üzerinde düşünceyi odaklama ve kendine hedef belirleyerek başarılı performans hayal etme değişkenlerini aynı yönde etkilediği belirlenmiştir. Buna göre umut düzeyi yüksek ve problemlerin çözümünde farklı ve yaratıcı alternatifler oluşturabilen işgörenlerin, hedeflediği davranışların olumlu yönlerine odaklandığı, bu davranışların sonuçlarına ilişkin iç görü sahibi olduğu ve performans başarısını zihninde resmederek motivasyon düzeyini arttırma çabası içinde olduğu iddia edilebilir.

Psikolojik sermayenin iyimserlik boyutu hayata dair genel olarak olumlu beklentiler içinde olmak ve yaşamı iyi yönleriyle kabullenmek anlamına gelmektedir. İyimser insanların genel olarak ılımlı, yapıcı, duygusal anlamda daha güçlü, başarısızlıklarında cesaretlerini daha kolay toparlayabilen bireyler oldukları bildirilmektedir (D'Intino vd., 2007; Carver vd., 2010). Yapılan diğer çalışmalarda da iyimserlik eğilimi yüksek bireylerin daha az duygusal tükenme yaşadığı (Çetin, Hazır ve Basım, 2013), öznel iyi oluş, yaşam doyumu ve olumlu duygulara sahip olma düzeylerinin arttğı (Quevedo, Abella ve Villalobos, 2014) ifade edilmektedir. Mevcut çalışmada iyimserlik alt boyutunun, öz-liderlik alt boyutlarından kendine hedef belirleyerek başarılı performans hayal etme, kendine hatırlatıcılar belirleme ve kendi kendine konuşma değişkenleri ile aynı yönde etkileşim halinde olduğu saptanmıştır. Dolayısıyla iyimserlik düzeyi yüksek çalışanların olumlu ve yapıcı iç diyaloglar yapma eğiliminde olduğu, planladığı ve başarısını zihninde hayal ettiği hedeflerinin olumlu yönde sonuçlanması için dış uyarıcıları hatırlatıcılarla kontrol altına almaya çalışabilecekleri ileri sürülebilir.

Psikolojik sermayenin psikolojik dayanıklılık alt boyutu, bireyin zorluklara ve değişim sürecine kolay uyum sağlayabilmesi ve stresli durumlarda sakinliğini ve gücünü koruyabilmesini ifade etmektedir (Coutu, 2002; Luthans, 2002). illgili çalışmalar, psikolojik olarak sağlıklı bireylerin yaratıcılık performanslarının (Taştan, 2016) ve iş tatmininin arttğını (Kaplan ve Biçkes, 2013), duygusal olarak tükenme eğilimlerinin azaldığını (Çetin vd., 2013) belirtmektedir. Mevcut çalışmada ise psikolojik dayanıkıı̆ı̆ın, öz-liderlik davranışlarından sadece kendine hatılatıcılar belirleme değişkeni ile ters yönlü bir ilişkide olduğu saptanmıştır. 
Diğer taraftan psikolojik sermayenin öz-yeterlilik alt boyutu ise bireyin başarabileceğine yönelik kendine inancını ve kararıı̆ı̆ını ifade etmektedir (Gist, 1987; Bandura, 1994). Bandura (1989) öz-yeterlilik düzeyi yüksek bireylerin kendileri için belirledikleri amaçlar doğrultusunda davranışlarına yön verebilecek yetiye sahip olduklarını iddia etmektedir. Bu iddiaya paralel olarak mevcut çalışmanın bulgularına göre de, öz-yeterlilik alt boyutu düşünce ve fikirlerini değerlendirme değişkeni ve kendine hatılatıcılar belirleme davranışını aynı yönde etkilemektedir. Dolayısıyla öz-yeterlilik düzeyi yüksek çalışanların, kendi düşünce süreçleri üzerinde denetim sahibi olduğu, zihinsel enerjisini performansının olumlu taraflarına yönlendirirdiği ve kendi geliştirdiği hatıllatıcı araçlar yoluyla da performansını üst düzeye çıkarmaya çalıştı̆ı iddia edilebilir.

Sonuç olarak bu çalışmada elde edilen bulgulara göre farklı öz-liderlik davranışları, farklı psikolojik sermaye faktörlerinden etkilenmektedir. Özellikle de umut ve iyimserlik düzeylerinin arttrılması, çalışanların öz-liderlik, öz-disiplin ve kendi kendini motive etme ve yönetebilme becerilerinin gelişmesinde önemli unsurlardan biri olarak değerlendirilmektedir. Bu kapsamda araştırma bulguları örgütsel alan uygulayıcıları için de çıkarımlar sunmaktadır. Örneğin yöneticiler çalışanların terfi ve işe alım süreçlerinde kişilik bazı değerlendirmeleri dikkate alarak umut ve iyimserlik düzeyi yüksek çalışanlardan oluşan bir iş gücü kompozisyonu yaratabilirler. Ayrıca insan kaynakları geliştirme uygulamalarına iyimserlik ve umut eğitimleri ya da akıl hocalığı programlarının (Snyder, 2000; Jenaabadi, 2014) dahil edilmesi çalışanların öz-liderlik düzeylerini arttrarak dışsal denetim mekanizmalarına daha az ihtiyaç duyulmasına olanak sağlayabilir.

Araştırmanın buraya kadar aktarılan tüm bu sonuçları, seçilen örneklem ve kullanılan ölçme araçlarıyla sınırlıdır. Nicel ve nitel olarak farklılaşan örneklem gruplarıyla yürütülecek çalışmalar daha genellenebilir sonuçlara ulaşma imkânı verebilecektir. Bunun yanı sıra, gelecekteki çalışmalarda kişilik özellikleri, örgüt kültürü ve yapısı, lider-üye etkileşimi, milli kültür değerleri gibi değişkenlerin, psikolojik sermaye ve öz-liderlik ilişkisiyle birlikte ele alınması konunun her yönüyle açıklanması bakımından fayda sağlayacaktır.

\section{Son Notlar}

1. Bu çalışmanın bir kısmı, Ankara'da yapılan 25. Ulusal Yönetim ve Organizasyon Kongresinde sunulmuştur. (Part of this study has been presented at the $25^{\text {th }}$ National Management and Organization Congress, Ankara, Turkey)

\section{Kaynaklar}

Akçay, V. H. (2011). Pozitif psikolojik sermayenin iş tatmini ile ilişkisi. Yayınlanmamış Doktora Tezi, İstanbul: İstanbul Üniversitesi SBE İşletme (íktisat) Fakültesi.

Anderson, J. S., \& Prussia, G. E. (1997). The self-leadership questionnaire: Preliminary assessment of construct validity. The Journal of Leadership Studies, 4(2), 119-143.

Aron, A. \& Aron, E. (1999). Statistics for psychology (2.ed.). Upper Saddle River, NJ: Prentice Hall.

Avey, J. B., Wernsing, T. S., \& Luthans, F. (2008). Can positive employees help positive organizational change? Impact of psychological capital and emotions on relevant attitudes and behaviors. The Journal of Applied Behavioral Science, 44(1), 48-70.

Avey, J. A., Reichard, R. J., Luthans, F., \& Mhatre, K. H. (2011). Meta-analysis of the impact of positive psychological capital on employee attitudes, behaviors, and performance. Human Resource Development Quarterly, 22(2), 127 152.

Bandura, A. (1977). Self-efficacy: Toward a unifying theory of behavioral change. Psychological Review, 84, $191-215$.

Bandura, A. (1989, September). Human agency in social cognitive theory. American Psychologist, 1175-1184.

Bandura, A. (1994). Self-efficacy. In V. S. Ramachaudran (Ed.), Encyclopedia of Human Behavior (Cilt 4, s. 71-81). New York: Academic Press.

Block, J., \& Kremen, A. M. (1996). IQ and ego-resiliency: Conceptual and empirical connections and separateness. Journal of Personality and Social Psychology, 70, 349-361. 
Carmeli, A., Meitar, R., \& Weisberg, J. (2006). Self-leadership skills and innovative behavior at work. International Journal of Manpower, 27(1), 75-90.

Carver, C. S., Scheiner, M. F., \& Segerstrom, S. C. (2010). Optimism. Clinical Psychology Review, 30, 879-889.

Cenciotti, R., Alessandri, G. \& Borgogni, L. (2017) Psychological capital and career success over time: The mediating role of job crafting. Journal of Leadership \& Organizational Studies, 24(3), 372-384.

Cheavens, J. S., Feldman, D. B., Woodward, J. T. \& Snyder, C. R. (2006). Hope in cognitive psychotherapies. Journal of Cognitive Psychotherapy, 20 (2), 135-145.

Coutu, D. L. (2002, May). How resilience works. Harvard Business Review, 1-9.

Culbertson, S. S. Fullagar, C. J. \& Mills, M. J. (2010). Feeling good and doing great: The relationship between psychological capital and well-being. Journal of Occupational Health Psychology, 15(4), 421-433.

Çetin, F. (2011). The effects of the organizational psychological capital on the attitudes of commitment and satisfaction: A public sample in Turkey. European Journal of Social Sciences, 21(3), 373-380.

Çetin, F. \& Basım, H. N. (2011). Psikolojik dayanıklılığın iş tatmini ve örgütsel bağlılık tutumlarındaki rolü. Işs, Güç Endüstri ilişkileri ve Insan Kaynakları Dergisi, 13(3), 79-94.

Çetin, F., \& Basım, H. N. (2012). Örgütsel psikolojik sermaye: Bir ölçek uyarlama çalışması. Amme idaresi Dergisi, 45(1), 121-137.

Çetin, F., Hazır, K., \& Basım, H. N. (2013). Destekleyici örgüt kültürü ile örgütsel psikolojik sermaye etkileşimi: Kontrol odağının aracılık rolü. H.Ü. iktisadi ve Idari Bilimler Fakültesi Dergisi, 31(1), 31-52.

Çetin, F., Şeşen, H., \& Basım, H. N. (2013). Örgütsel psikolojik sermayenin tükenmişlik sürecine etkileri: Kamu sektöründe bir araştirma. Anadolu University Journal of Social Sciences, 13(3), 95-107.

Davis, T. R., \& Luthans, F. (1980). A social learning approach to organizational behavior. Academy of Management Review, 5(2), 281-290.

D'Intino, R. S., Goldsby, M. G., Houghton, J. D., \& Neck, C. P. (2007). Self-Leadership: A process for entrepreneurial success. Journal of Leadership and Organizational Studies, 13(4), 105-120.

DiLiello, T. C., \& Houghton, J. D. (2006). Maximizing organizational leadership capacity for the future: Toword a model of self-leadership, innovation and creativity. Journal of Managerial Psychology, 21(4), 319-337.

Dina, V. K., Lester, P. B. \& Harms, P. D. (2015). Effects of psychological capital on mental health and substance abuse. Journal of Leadership \& Organizational Studies, 22(3), 280-291.

Frayne, C. A., \& Latham, G. P. (1987). Application of social-learning theory to employee self-management of attendance. Journal of Applied Psychology, 72, 387-392.

Gist, M. E. (1987). Self-efficacy: Implication for organizational behavior and human resource management. Academy of Management Review, 12(3), 472-485.

Houghton, J. D., \& Jinkerson, D. L. (2007). Constructive thought strategies and job satisfaction: A preliminary examination. Journal of Business and Psychology, 22, 45-53.

Houghton, J. D., \& Neck, C. P. (2002). The revised self-leadership questionnaire. Journal of Managerial , 17(8).

Jafri, H. (2012). Psychological capital and innovative behavior: An empirical study on apparel fashion industry. The Journal of Contemporary Management Research, 6(1), 42-52.

Jenaabadi, H. 2014. The effect of training skills of optimism on fostering emotional intelligence of males in education \& improvement center in Zahedan. Procedia-Social and Behavioral Sciences, 114: 191-196.

Kaplan, M. \& Biçkes, D. M. (2013). The relationship between pscychological capital on job satisfaction: A study of hotel businesses in Nevşehir. Yönetim ve Ekonomi, 20 (2), 233-242.

Konradt, U., Andreßen, P., \& Ellwart, T. (2009). Self-leadership in organizational teams: A multilevel analysis of moderators and mediators. European Journal of Work and Organizational Psychology, 18(3), 322-346.

Kotze, M. (2017). The influence of psychological capital, self-leadership, and mindfulness on work engagement. South African Journal of Psychology, 1-4.

Latham, G. P., \& Locke, E. A. (1979). Goal setting-A motivational technique that works. Organizational Dynamics, 8, 6880.

Locke, E. A., \& Latham, G. P. (2006). New directions in goal-setting theory. Current Directions in Psychological Science, 15(5), 265-268. 
Luthans, F. (2002). The need for and meaning of positive organizational behavior. Journal of Organizational Behavior, 23, 695-706.

Luthans, F., Luthans, K. W., \& Luthans, B. C. (2004). Positive psychological capital: Beyond human and social capital. Business Horizons, 47(1), 45-50.

Luthans, F. \& Youssef, C. M. (2004). Human, social, and now psychological capital management. Organizational Dynamics, 33, 143-160.

Luthans, F., Avolio, B. J., Avey, J. B., \& Norman, S. M. (2007). Positive psychological capital: Measurement and relationship with performance and satisfaction. Personnel Psychology, 60, 541-572.

Luthans, F., Norman, S. M., Avolio, B. J., \& Avey, J. B. (2008). The mediating role of psychological capital in the supportive organizational climate - employee performance relationship. Journal of Organizational Behavior, 29, 219-238.

Luthans, F., Avey, J. B., Avolio, B. J., \& Peterson, S. J. (2010). The development and resulting performance impact of positive psychological capital. Human Resource Development Quarterly, 21(1), 41-67.

Luthans, F., Youssef, C. M., \& Rawski, S. L. (2011). A tale of two paradigms: The impact of psychological capital and reinforcing feedback on problem solving and innovation. Journal of Organizational Behavior Management, 31(4), 333-350.

Luthar, S. S., Cicchetti, D., \& Becker, B. (2000). The Construct of Resilience: A critical evaluation and guidelines for future work. Child Development, 71(3), 543-562.

Manz, C. C., \& Sims, H. P. (1980). Self-management as a substitute for leadership: A social learning theory perspective. Academy of Management Review, 5(3), 361-367.

Manz, C. C. (1986). Self-leadership: toward an expanded theory of self-influence processes in organizations. Academy of Management Review, 11(3), 585-600.

Manz, C. C., \& Sims, H. P. (1991). Super leadership: Beyond the myth of heroic leadership. Organizational Dynamics, 19, 18-35.

Marques-Quinteiro, P., \& Curral, L. A. (2012). Goal orientation and work role performance: Predicting adaptive and proactive work role performance through self-leadership strategies. The Journal of Psychology, 146(6), 559-577.

Mills, M. J., Fleck, C. R., \& Kozikowski, A. (2013). Positive psychology at work: A conceptual review, state-of-practice assessment, and a look ahead. The Journal of Positive Psychology, 8(2), 153-164.

Neck, C. P. (1996, April). Thought Self-Leadership: A self-regulatory approach towards overcoming resistance to organizational change. The International Journal of Organizational Analysis, 4(2), 202-216.

Neck, C. P., \& Manz, C. C. (1992). Thought self-leadership: The influence of self-talk and mental imagery on performance. Journal of Organizational Behavior, 13, 681-699.

Neck, C. P., \& Manz, C. C. (1996). Thought self-leadership: The impact of mental strategies training on employee behavior, cognition, and emotion. Journal of Organizational Behavior, 17, 445-467.

Norman, S. M., Avey, J. B., Nimnicht, J. L., \& Pigeon, N. G. (2010). The interactive effects of psychological capital and organizational identity on employee organizational citizenship and deviance behaviours. Journal of Leadership \& Organizational Studies, 17, 380-391.

Park, G.-R., Moon, G.-W., \& Hyun, S.-E. (2014). An impact of self-leadership on innovative behavior in sports educators and understanding of advanced research. The SIJ Transactions on Industrial, Financial \& Business Management, 2(3), 117-122.

Pearce, C. L., \& Manz, C. C. (2005). The new silver bullets of leadership: The importance of self- and shared leadership in knowledge work. Organizational Dynamics, 34(2), 130-140.

Peterson, S. J., \& Byron, K. (2008). Exploring the role of hope in job performance: Results from four studies. Journal of Organizational Behavior, 29, 785-803.

Prussia, G. E., Anderson, J. S., \& Manz, C. C. (1998). Self-leadership and performance outcomes: The mediating influence of self-efficacy. Journal of Organizational Behavior, 19, 523-538.

Quevedo, R. J. M., Abella, M. C. \& Villalobos, J. A. G. (2014). Relationship between subjective well-being, optimism and demogrophic variables in college students of the University of San Luis Potosi in Mexico. Universitas Psychologica, 13 (3), 1083-1098.

Rego, A., Sousa, F., Marques, C. \& Cunha, M. P. e. (2012) Optimism predicting employees' creativity: The mediating role of positive affect and the positivity ratio. European Journal of Work and Organizational Psychology, 21(2), 244270. 
Seligman, M. E., \& Csikszentmihalyi, M. (2000). Positive psychology. American Psychologist, 55(1), 5-14.

Şeşen, H., Tabak, A. \& Arli, Ö. (2017). Consequences of self-leadership: A study on primary school teachers. Educational Sciences: Theory \& Practice, 17(3): 945-968.

Sharma, S. K. \& Sharma, S. (2015). Psychological capital as a predictor of workplace behavior. Journal of Management Research, 15, 60-70.

Snyder, C. R., Harris, C., Anderson, J. R., Holleran, S. A., Irving, L. M., Sigmon, S. T., \& vd. (1991). The will and the ways: Development and validation of an individual-differences measure of hope. Journal of Personality and Social Psychology, 60, 570-585.

Snyder, C. R., Sympson, S. C., Ybascon, F. C., Borders, T. F., Babyak, M. A., \& Higgins, R. L. (1996). Development and validation of the state of hope scale. Journal of Personality and Social Psychology, 70(2), 321-335.

Snyder, C. R. (2000). Handbook of Hope. San Diego: Academic Press.

Sweetman, D., Luthans, F., Avey, J. B., \& Luthans, B. C. (2011). Relationship between positive psychological capital and creative performance. Canadian Journal of Administrative Sciences, 28(1), 4-13.).

Tabak, A., Sığrı, Ü., \& Türköz, T. (2013). Öz-liderlik ölçeğinin türkçeye uyarlanması. Türk Dünyası Sosyal Bilimler Dergisi (67), 303-309.

Taştan, S. B. (2016). Psychological capital: A positive psychological resource and its relationship with creative performance behavior. Anadolu University Journal of Social Sciences, 16 (2), 111-118.

Tierney, P., \& Farmer, M., S. (2002). Creative self-efficacy: Its potential antecedents and relationship to creative performance. The Academy of Management Journal, 45(6): 1137-1148.

$\mathrm{Wu}$, S. (2015). Exploring the effects of psychological capital and social capital on team creativity in ISD teams. The International Journal of Organizational Innovation, 7(3), 34-46.

Youssef, C. M., \& Luthans, F. (2007). Positive organizational behavior in the workplace: The impact of hope, optimism, and resilience. Journal of Management, 33(5), 774-800. 
This Page Intentionally Left Blank 